\title{
Analysis Factors Affecting the Demand and Supply of Local Chicken Meat in Pakpak Bharat Regency
}

\author{
Mizanul Akbar' ${ }^{1}$ Hasnudi², Tavi Supriana $^{3}$ \\ ${ }^{1,2,3}$ Universitas Sumatera Utara, Indonesia \\ mizakbar@gmail.com
}

\begin{abstract}
Food needs are basic human needs that must be met. One of the food needs comes from animal sources, the source of meat most consumed in Pakpak Bharat is local chicken. From the consumer side, the factors that affect the demand for local chicken include: the price of local chickens, the price of tilapia, population and income, and factors that affect the demand for local chicken include: the price of local chicken, the price of local chicken feed and the price of local chicken seeds. The purpose of this study is to analyze the factors that affect the demand and supply of local chickens in Pakpak Bharat Regency in 2010 - 2019, to forecast the production of local chicken in Pakpak Bharat Regency in 2020-2029. Data analysis was performed using the Ordinary Least Square (OLS) method with multiple linear regression estimation models using the help of the SPSS 20 program. The estimation results of the demand model are variables of tilapia meat prices (X2), population (X3), and per capita income (X4) has a positive and significant effect on the demand for local chicken $(Y)$, while the price variable for local chicken meat (XI) has a negative and significant effect on the demand for local chicken meat $(Y)$. The estimation results of the model offer variable price for local chicken meat (X1) have a positive and significant effect on the supply of local chickens $(Y)$, while for the variable price of local chicken feed $(X 2)$ and the price of local chicken seeds (X3) have a negative and significant effect on offering local chicken meat $(Y)$. Simultaneously, all variables of the demand and supply of local chicken meat have a positive effect. Resultthe projection trend of local chicken production in Pakpak Bharat Regency in 2020-2029 is a positive trend or has increased every year.
\end{abstract}

\author{
Keywords \\ local chicken demand local \\ chicken supply, local chicken \\ production forecasting
}

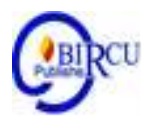

\section{Introduction}

Efforts to Increase Health Degrees in Indonesia until now have not been considered to have an Continuation of Health Development Continuation, this is when compared to neighboring Countries Health Degrees in Indonesia are still considered low. One indicator of the success of development for the development of an ideal nation is the establishment and organization of a good health system, in this discussion covering physical and psychological aspects which are added with spiritual conditions, personality and empowerment. This aspect discusses the discussion space on health development which is interrelated with other aspects. (Shinta et al, 2020)

Food needs are basic human needs that must be met. The food needs, among others, come from food products of animal origin. Animal protein is needed to improve the quality of human resources. Animal protein is found in foods such as eggs, meat, milk, fish and poultry. One of the livestock meats that is easily available is chicken meat. Chicken meat is one of the 
meats that are widely consumed by the public both in the form of meat and its processed products.

Meat is widely consumed by people because it has a good taste and high nutrient content. One of the most common sources of meat consumed by Indonesians is chicken. Chicken meat provides a very large contribution to the fulfillment of animal protein needs. About $62 \%$ of national meat consumption comes from chicken.

Local chicken is a domestic resource owned by the Indonesian people which are generally maintained by farmers in rural areas. The actors in the demand for local chickens are consumers, while those who offer local chickens are the Local chicken breeders. In conducting supply and demand, consumers and breeders are influenced by several factors. From the consumer side, these factors include the price of local chicken itself, the price of substituted meat, income, and the number of dependents, and from the farmer it depends on the amount of local chicken supply in each region.

The increase in the contribution of local chicken meat as a source of animal protein can be approached from the demand and supply side. From the demand side, the lack of demand for local chicken meat is predictable because some people still consider it a luxury consumption, so that the demand is only on certain days (big days). According to data (Animal Husbandry and Animal Health Statistics, 2017) the consumption of local chicken meat is $626,000 \mathrm{Kg} /$ capita / year while the consumption of purebred chickens is $5,110,000 \mathrm{Kg} /$ capita / year (Animal Husbandry and Animal Health Statistics, 2017).

Broadly speaking, there are three types of livestock that have the highest population in Pakpak Bharat, namely local chickens, pigs and ducks. Local chicken is the animal product in the livestock sector with the highest population in Pakpak Bharat, when compared to other types of livestock (BPS, 2019). The price of local chicken is classified as high in Pakpak Bharat Regency with the condition of the people's income per capitas. Meanwhile, the price of chicken will certainly affect the demand for local chicken meat itself.

Demand is a description of the number of products that buyers as consumers will buy at certain times and situations. Time periods can be categorized in years or months. While the situation that is considered in demand is the price of the product itself, the price of other products, consumer income and other things (Arsyad, 2000). Consumers will certainly make a decision to make a purchase by considering the things above as well.

The relatively high price of local chicken meat and the low purchasing power of the community (low per capita income) are also predicted to be factors that influence the lack of demand for local chicken meat. The relatively cheaper price of tilapia also affects consumers in changing the type of protein source.

Although the community's demand for local chickens fluctuates, at certain times the demand for local chickens is very high, such as for celebrations, holidays and so on. There will always be a tendency for local chicken demand at any time, because the market potential for local chickens is quite large. When the price of meat increases, the community will substitute the meat for local chicken so that the demand will increase.

The population of local chickens in Pakpak Bharat Regency is 133,517 tails (Pakpak Bharat Regency in Figures, 2018) while the population of Pakpak Bharat Regency is 47,183 people (Pakpak Bharat Regency in Figures, 2018) which is estimated to also have a fairly high consumption need for local chicken meat or their products are sold outside the district. This can be seen from the increase in the population growth of local chickens from 2014 to 2018 which is greater when compared to the population growth chart in Pakpak Bharat Regency in 2014 - 2018.

The number of local chickens offered from year to year has increased. The chicken seller / trader can choose between selling the chicken for money or holding the product for 
his own use. The seller's desire or unwillingness to hold on to his product determines the demand for his own product, while supply is a supply that is manifested in a mathematical relationship with the factors that influence it, namely chicken prices, feed costs and seed prices.

So from the description above the writer is interested in conducting research on the factors that influence the demand and supply of local chicken in Pakpak Bharat Regency, given the important role of local chicken as a national meat supplier in general and also for Pakpak Bharat Regency because local chicken is part of the typical food.

\section{Review of Literatures}

\subsection{Local Chicken Farming Sector in Pakpak Bharat Regency}

The livestock sector which is also included in agribusiness is one of the phenomena that will grow rapidly when the land base becomes limited. The demands of an integrated farming system are becoming increasingly rational in line with the very limited demands for efficiency and effectiveness in the use of land, labor, capital and other production factors. The livestock sub-sector as one of the agricultural sub-sectors plays a role in meeting the nutritional needs of the community's protein and one of the protein sources can be obtained from chicken meat (Arifin, 2004 in Kurniati, 2014). The largest population of meat sources in Pakpak Bharat is local chicken. The highest number of local chickens in 2017 was in Sitellu Teli Urang Jehe Subdistrict, namely 30,827 tails and the smallest local chickens were in Pagindar District 2,735 tails.

Table 1. Local chicken Population from The Largest According to District in Pakpak Bharat Regency 2016 - 2017

\begin{tabular}{llcc}
\hline No. & \multicolumn{1}{c}{ Districts } & Year 2016 & Year 2017 \\
\hline 1. & Sitellu Teli Urang Jehe & 29.872 & 30.827 \\
2. & Salak & 28.077 & 29.041 \\
3. & Sitellu Tali Urang Julu & 17.850 & 18.654 \\
4. & Tinada & 14.353 & 15.199 \\
5. & Kerjaan & 14.369 & 15.075 \\
6. & Siempat Rube & 13.326 & 14.265 \\
7. & Pergetteng-getteng Sengkut & 6.684 & 7.721 \\
8. & Pagindar & 1.992 & 2.735 \\
\hline Total & & 126.523 & 133.517 \\
\hline
\end{tabular}

Source: Central Bureau of Statistics of Pakpak Bharat Regency, 2016 - 2017

\subsection{Local Chicken}

Local chicken is a type of poultry that is still natural in the sense that the word has not received genetic improvement treatment. In terms of economic benefits, local chickens are relatively few compared to purebred chickens, both in egg production and in the ability to produce meat. However, local chickens are already popular among the consumer community as a popular type of meat and egg producer. On that basis, the encouragement of this demand also affects the development of local chicken rearing (Sayuti, 2002).

Local chicken is a local poultry whose population is spread throughout Indonesia. Local poultry has great potential to be developed because it has a very important role in fulfilling family nutrition adequacy, increasing family income and being used as savings for breeders (Dewat and Sihombing, 2012). 
The local chicken farm in Pakpak Bharat Regency has great prospects. According to Utomo (2015), the increase in population from year to year, the level of community income and public education will also lead to an increase in demand for animal products, especially meat. On the other hand, it will also have a positive impact on breeders. The increasing demand for chicken meat can also increase the income of chicken farmers. In his study, it was found that the farm with the highest chicken population had the highest income. Meanwhile, Kurniati's (2014) study shows that in general the chicken farming sector plays a role in the regional economy because it is a basic sector, so that it can meet the needs of its own region.

\subsection{Demand and Supply of Local Chicken}

The demand for local chickens generally comes from residents with high incomes. This is also mentioned in the study of Nurtini et.al (1998) in Hadini et al. (2011) stated that in the high income group, which is relatively more capable of choosing, they prefer local chicken to broiler meat. This is also related to the health preference that local chicken meat tends to be less fatty than broiler chicken meat. In Rosmiyati (2002), it is stated that the economic value of local chickens tends to increase from year to year due to the production of local chickens that are free from drug residues, antibiotics and so on.

The increase in prices for these two types of inputs should lead to a decrease in supply for broilers. An increase in input prices will cause production costs to increase, this increased production cost will cause a decrease in the level of production produced by farmers, thus the supply will also decrease (Tomek \& Robinson, 1972 in Hartono, 2012).

\subsection{Demand Theory}

The amount of demand (quantity demanded) of a product is the number of products that buyers are willing and able to pay (Mankiw, 2006). There are many variables that affect the amount of demand for a product. Mankiw (2006) states that the price of the product, income, the price of the related product, tastes, expectations and the number of buyers are several factors that can determine the size of the amount of demand. The law of demand states that, if everything is left the same, when the price of a product increases, the quantity demanded will decrease, and when the price falls, the quantity demanded will increase. So it can be said that the quantity demanded is negatively related to price. As seen in Figure 2, the demand curve ( $\mathrm{D}=$ demand) decreases from left to right. The horizontal axis with $\mathrm{q} / \mathrm{t}$ (quantity per unit of time) is the quantity axis or the number of products, while the vertical axis is $\mathrm{P}$ (price) or product price (Siahaan, 2011).

Another thing that most determines demand is of course taste, but economists usually do not try to explain people's tastes because tastes are based on historical as well as psychological forces that are outside the realm of economics. However, economists examine what happens when people's tastes change (Mankiw, 2006). Rohim (2017) there are several things that can affect demand, such as:

1. The price of the product itself, as a law of demand that the amount of demand for a product will increase when the price of the product decreases and vice versa.

2. The price of substituted products, namely the price of the product that can replace the product's position.

3. Consumer income, increased consumer income related to the purchasing power of consumers for a product.

4. Consumer tastes, tastes or related preferences also have an influence on the demand for a product. The demand for local chickens is higher due to the health preferences of consumers, that local chickens are free of drug, antibiotic and other residues.

5. Population, although it is stated in Sukirno (2008) that an increase in population does not automatically cause demand to increase. However, this is usually followed by the development 
of job opportunities so that people's income increases. Nuraini (2014) states that as income increases, the people's purchasing power also increases.

Apart from the five factors above, there are many other factors that can influence the demand for a product. Such as estimated future prices, income distribution, producer efforts to increase sales and so on.

\subsection{Supply Theory}

The supply (quantity supplied) of a product is the amount of product that the seller is willing and able to sell (Mankiw, 2006). There are many things that determine the amount of product offered, but when we analyze how the market works, one of the determinants is the price of the product. Besides that, it is also stated that: input prices, technology, expectations, and the number of sellers can affect the amount of supply. The law of supply states that, if everything is left the same, when the price of a product increases, the quantity of supply will increase, and when the price falls, the quantity of supply will also decrease. It can be said that the amount of supply is positively related to price (Siahaan, 2011).

The supply curve is a curve that shows the relationship between the price level of a particular product and the quantity of that product offered by the seller. This curve is made on the basis of real data regarding the relationship between the price level of the product and the number of product offers stated in the list of offers (supply table). The supply function is an equation that shows the relationship between the number of products offered by the seller and all the factors that influence it (Nuhfil and Kardono. Makr Economic Theory: Graphic and Mathematical Approaches. (Malang: Faculty of Economics, Brawijaya University, 2004).

\section{Research Methods}

The research area was determined purposively (intentionally), namely in Pakpak Bharat Regency. The basis for the appointment of Pakpak Bharat Regency as the research location is because Pakpak Bharat Regency is one of the production centers for local chicken meat in North Sumatra Province. Data used in this research is time series data with a range of 2010 2019 which were analyzed with the help of the SPSS (Statistical Package for Social Science) Version 20 program. To conduct an analysis on the identification of the first problem, in the form of analyzing the growth trend of local chickens in Pakpak Bharat Regency. This trend is seen from the graph formed by the production data of local chicken meat in Pakpak Bharat Regency in the period 2010 - 2019. Meanwhile, to analyze the identification of the second problem which looks at the factors that influence the demand and supply of local chicken meat simultaneously and Partially tested using multiple linear regression models, utilizing the SPSS program with the model equation for local chicken demand as follows:

Where:

$$
Q_{d}=\mathbf{a}_{0}+\mathbf{a}_{1} \mathbf{P}_{1}+\mathbf{a}_{2} \mathbf{P}_{2}+\mathbf{a}_{3} \mathbf{P}_{3}+\mathbf{a}_{4} \mathbf{P}_{4}+\mathbf{e}_{1}
$$

$$
\begin{aligned}
& \mathrm{Qd}=\text { Demand for local chicken }(\mathrm{Kg} / \text { capita } / \text { year }) \\
& \mathrm{a} 0=\text { Demand constant } \\
& \text { a1-n = Free variable regression coefficient of demand } \\
& \mathrm{P} 1=\text { Price of local chicken }(\mathrm{Rp} / \mathrm{Kg}) \\
& \mathrm{P} 2=\text { Price of tilapia fish }(\mathrm{Rp} / \mathrm{Kg}) \\
& \mathrm{P} 3=\text { total population (soul) } \\
& \text { P4 = income per capita (IDR / month) } \\
& \text { e1 = Bully error }
\end{aligned}
$$

While the equation of the Local chicken Offer model is as follows: 


$$
\mathbf{Q}_{s}=\mathbf{a}_{0}+\mathbf{a}_{1} \mathbf{P}_{1}+\mathbf{a}_{2} \mathbf{P}_{2}+\mathbf{a}_{3} \mathbf{P}_{3}+\mathbf{e}_{1}
$$

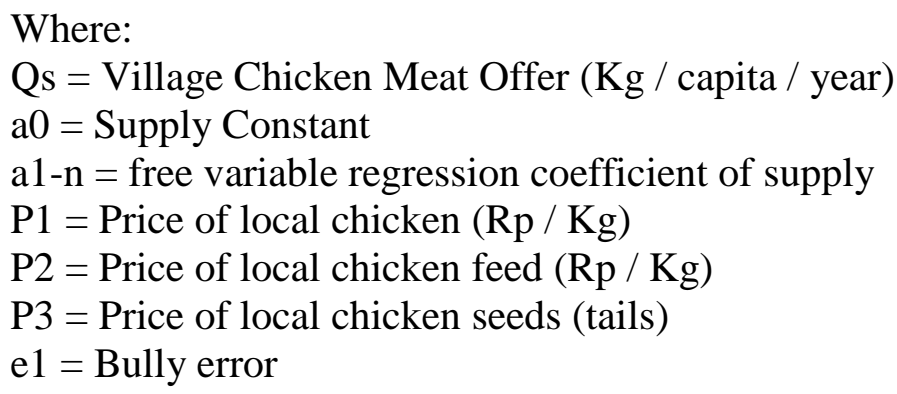

The $t$ test is a partial test of the effect of independent variables on the dependent variable. The significant level of local chicken $(\alpha)$ used in social science is 5\% (Firdaus, 2011). Testing Criteria: If sig. $\mathrm{t} \leq 0.05$ then $\mathrm{H} 0$ is rejected and $\mathrm{H} 1$ is accepted. If sig. $\mathrm{t}>0.05$, then $\mathrm{HO}$ is accepted and $\mathrm{H} 1$ is rejected. The activity of analyzing data in this study includes several basic stages that must be passed, in the form of a classic assumption test (Sutrisno, 2004).

\section{Result and Discussion}

\subsection{Growth Trend of Local Chickens in Pakpak Bharat Regency}

In 2010 - 2019 the total production of Local chicken meat was 141,570 kg or an annual average of $14,157 \mathrm{~kg}$ with an average growth of $31.7 \%$ for 10 years. The growth condition of local chickens in Pakpak Bharat Regency in the period 2010-2019 in Pakpak Bharat Regency has fluctuated from 2010-2019 which tends to increase every year which means experiencing a positive trend. Based on data from the Pakpak Bharat Regency Agriculture Office (2019), it shows that the highest local chicken production in 2019 was $18,600 \mathrm{~kg}$ and the lowest local chicken production in 2012 was $9,960 \mathrm{~kg}$. The average production of local chickens from 2010 to 2019 was $14,157 \mathrm{~kg}$ and you can see that the prospect of local chicken development is quite good in Pakpak Bharat Regency because the curve trend is positive, meaning that it has increased every year.

\subsection{Factors Affecting the Demand for Local Chicken Meat in Pakpak Bharat Regency}

From the data analysis method, it is known that the variables that can influence the demand for Local chicken meat in Pakpak Bharat Regency are the price of local chicken meat (X1), the price of tilapia meat (X2), population (X3), per capita income (X4). From the independent variables or independent variables, it will be seen how much influence it has on the demand for local chicken meat as the dependent or dependent variable. To test its effect, it is necessary to test with the multiple linear regression method using SPSS 20 either partially or simultaneously.

\section{a. Classical Assumption Test Results (Normality Test)}

The table below shows that the data in this study were normally distributed. This can be seen from the results of Kolmogorov-Smirnov calculations, namely: the price of village chicken meat $(\mathrm{X} 1)$, the price of tilapia meat (X2), population (X3), per capita income (X4), and the demand for local chicken meat (Y) obtained value asymp.sig of $0.345>0.05$ means that all variables are normally distributed. So that this research can be continued to the next test. 
Table 2. Normality Test Results

One-Sample Kolmogorov-Smirnov Test

\begin{tabular}{|ll|r|}
\hline & & \multicolumn{2}{|c|}{ Unstandardized } \\
\hline $\mathrm{N}$ & Residual \\
\hline Normal Parameters ${ }^{\mathrm{a}, \mathrm{b}}$ & Mean & 10 \\
& Std. Deviation & $0 \mathrm{E}-7$ \\
& Absolute & 01285347 \\
Most Extreme Differences & Positive & 296 \\
& Negative & 296 \\
Kolmogorov-Smirnov Z & &,- 139 \\
Asymp. Sig. (2-tailed) & &, 936 \\
\hline
\end{tabular}

a. Test distribution is Normal.

b. Calculated from data.

Source: Data processed with SPSS 20

\section{b. Autocorrelation Test}

The autocorrelation test is done by looking at the comparison of the calculated DurbinWatson value (dw) with the Durbin-Watson table value ( $\mathrm{dL}$ and $\mathrm{du}$ ). Where the DurbinWatson value (dw) obtained from the regression results is 2.3646 while the $\mathrm{dL}$ and $\mathrm{dU}$ values can be seen in the Durbin-Watson table at a significance of 0.05 . With $n=10, k=5$, then the Degree of Freedom (df) is used, namely df $1=k=5$ and df $2=n-k=5$, so that the values of $\mathrm{dL}=0.3760$ and $\mathrm{du}=2.4137$ are obtained.

Table 3. Autocorrelation Test Results of Model Summary ${ }^{\mathrm{b}}$

\begin{tabular}{|c|r|r|r|r|r|}
\hline Model & R & R Square & $\begin{array}{c}\text { Adjusted R } \\
\text { Square }\end{array}$ & $\begin{array}{c}\text { Std. Error of the } \\
\text { Estimate }\end{array}$ & Durbin-Watson \\
\hline 1 &, $988^{\mathrm{a}}$ &, 976 &, 957 &, 01724473 & 2,3646 \\
\hline
\end{tabular}

a. Predic4tors: (Constant), $\mathrm{x} 4, \mathrm{x} 3, \mathrm{x} 2, \mathrm{x} 1$

b. Dependent Variabel: $y$

Source: Data processed with SPSS 20

It can be concluded that the value of dw (Durbin-Watson) is 2.364 located in the area of $4-\mathrm{dU} \leq \mathrm{dw} \leq \mathrm{dU}(1,5863 \leq 2,3646 \leq 2,4137)$. This proves that there is no autocorrelation in the regression model for Kampung meat demand in Pakpak Bharat Regency.

\section{c. Multicollinearity Test}

The multicollinearity test in this study was carried out by looking at the Tolerance value and the Variance Inflating Factor (VIF) value. If the tolerance value approaches 1, and the VIF is between numbers 1 to 10, multicollinearity does not occur (Santoso, 2000). 
Table 4. Multicollinearity Test Results of Coefficients ${ }^{\mathrm{a}}$

\begin{tabular}{|c|c|c|c|c|c|c|c|}
\hline \multirow[t]{2}{*}{ Model } & \multicolumn{2}{|c|}{$\begin{array}{c}\text { Unstandardized } \\
\text { Coefficients }\end{array}$} & \multirow{2}{*}{$\begin{array}{c}\text { Standardized } \\
\text { Coefficients } \\
\text { Beta }\end{array}$} & \multirow[t]{2}{*}{$\mathrm{t}$} & \multirow[t]{2}{*}{ Sig. } & \multicolumn{2}{|c|}{$\begin{array}{l}\text { Collinearity } \\
\text { Statistics }\end{array}$} \\
\hline & $\mathrm{B}$ & Std. Error & & & & Tolerance & VIF \\
\hline (Constant) & $-9,239$ & 1,070 & & $-8,632$ & ,000 & & \\
\hline $\begin{array}{l}\text { Local Chicken } \\
\text { Prices (X1) }\end{array}$ &,- 104 & , 028 &,- 370 & $-3,755$ & ,013 & 496 & 2,017 \\
\hline $\begin{array}{l}\text { The price of Tilapia } \\
\text { meat (X2) }\end{array}$ & ,068 & ,026 & , 190 & 2,585 & ,049 & ,892 & 1,121 \\
\hline $\begin{array}{l}\text { Total population } \\
\text { (X3) }\end{array}$ & 2,765 & , 247 & 892 & 11,218 & , 000 & ,762 & 1,313 \\
\hline $\begin{array}{l}\text { Income per capita } \\
\text { (X4) }\end{array}$ & 212 & ( & 408 & 4,370 & ,007 & ,551 & 1,815 \\
\hline
\end{tabular}

a. Dependent Variabel: y

Source: Data processed with SPSS 20

Based on table 4 the independent variable has a VIF value between 1 - 10, and a tolerance value less than 1 , so the data does not occur multicollinearity.

\section{d. Heteroscedasticity Test}

According to Ghozali (2001) the basis for decision making for the heteroscedasticity test is:

a) If there is a certain pattern, such as the existing dots forming a certain regular pattern (wavy, melting, then narrowing), it indicates that heteroscedasticity has occurred.

b) If there is no clear pattern, and the dots spread above and below the 0 on the Y axis, then there is no heteroscedasticity.

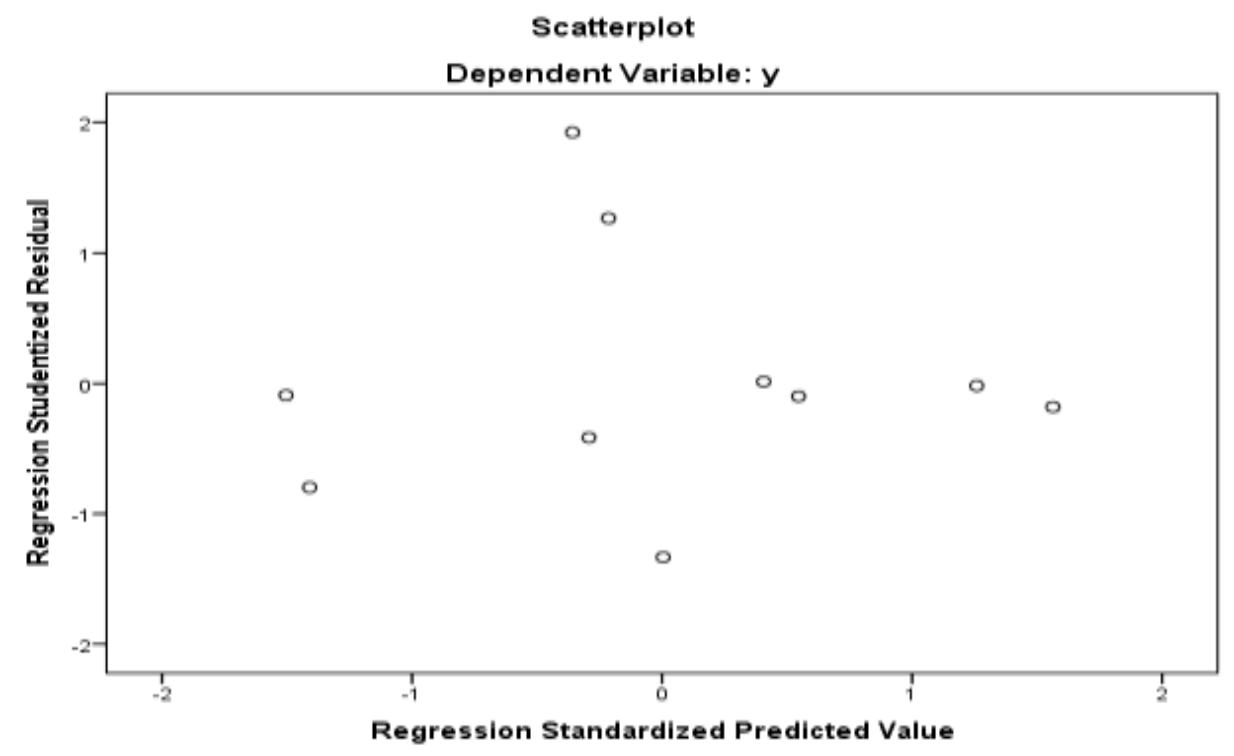

Source: Data processed with SPSS 20

Figure 1. Position of the Scatterplot in the Heteroscedasticity Test

From the scatter plot in Figure 1, it can be seen that the dots spread out with an unclear pattern above and below the number 0 on the $\mathrm{Y}$ axis. So in the regression model for Local chicken meat supply in Pakpak Bharat Regency there is no heteroscedasticity problem. 


\section{d. Multiple Linear Regression Calculation}

Table 5. Results of Multiple Linear Regression Calculations of Coefficients ${ }^{\mathrm{a}}$

\begin{tabular}{|c|c|c|c|c|c|}
\hline \multirow[t]{2}{*}{ Model } & \multicolumn{2}{|c|}{ Unstandardized Coefficients } & $\begin{array}{l}\text { Standardized } \\
\text { Coefficients }\end{array}$ & \multirow[t]{2}{*}{$\mathrm{t}$} & \multirow[t]{2}{*}{ Sig. } \\
\hline & $\mathrm{B}$ & Std. Error & Beta & & \\
\hline (Constant) & 3,843 & 255 & & 15,084 &, 000 \\
\hline $\begin{array}{l}\text { Price of local chicken } \\
\text { meat }(\mathrm{X} 1)\end{array}$ & ,352 & ,026 & ,747 & 13,691 &, 000 \\
\hline $\begin{array}{l}\text { Price of local chicken } \\
\text { feed (X2) }\end{array}$ &,- 075 & ,028 &,- 132 & $-2,649$ & ,038 \\
\hline $\begin{array}{l}\text { Price of local chicken } \\
\text { seeds (X3) }\end{array}$ &,- 139 & ,023 &,- 231 & $-6,029$ & 001 \\
\hline
\end{tabular}

a. Dependent Variabel: Y

Source: Data processed with SPSS 20

From the results of data processing in table 5, the regression equation can be made as follows:

$$
\begin{gathered}
Y=a+b_{1} X_{1}+b_{2} X_{2}+b_{3} X_{3}+e_{i} \\
Y=3,843+0,352 X_{1}-0,075 X_{2}-0,139 X_{3}+e_{i}
\end{gathered}
$$

The explanation of the multiple linear regression equation can be described as follows:

a. The constant value (a) is 3,843 , meaning that if the independent variable is the price of local chicken meat (X1), the price of local chicken feed (X2), local chicken seed (X3) is constant, the offer of local chicken meat increases by $3843 \mathrm{~kg}$.

b. The regression coefficient value of the village chicken meat price variable (b1) is 0.352 , meaning that if the price of local chicken meat (X1) increases by Rp. 1000, - / kg while the other variables are constant, the offer of local chicken meat will increase by $352 \mathrm{~kg}$.

c. The regression coefficient value of the price of local chicken feed (b2) is -0.075 , meaning that if the price of local chicken feed (X2) increases by Rp. 1000, - / kg while the other variables are constant, then the offer of Local chicken meat will decrease by $75 \mathrm{~kg}$.

$\mathrm{d}$. The value of the regression coefficient variable for the price of local chicken seeds (b3) is -0.139 , meaning that if the price of local chicken seeds (X3) increases by Rp. 1000, - / kg while the other variables are constant, the offer of Local chicken meat will decrease by $139 \mathrm{~kg}$.

\section{e. Partial Hypothesis Testing (t-test)}

Table 6. Results of the t test calculation of Coefficients ${ }^{\mathrm{a}}$

\begin{tabular}{|l|r|r|r|r|r|}
\hline \multirow{2}{*}{ Model } & \multicolumn{2}{|c|}{ Unstandardized Coefficients } & \multicolumn{2}{c|}{$\begin{array}{c}\text { Standardized } \\
\text { Coefficients }\end{array}$} & \multirow{2}{*}{ Sig. } \\
\cline { 2 - 5 } & \multicolumn{1}{|c|}{$\mathrm{B}$} & Std. Error & Beta & 15,084 &, 000 \\
\hline (Constant) & 3,843 &, 255 & &, 000 \\
Local chicken Prices &, 352 &, 026 &, 747 & 13,691 &, 038 \\
(X1) &,- 075 &, 028 &,- 132 & $-2,649$ &, 001 \\
Feed Prices (X2) &,- 139 &, 023 &,- 231 & $-6,029$ &, \\
Price of local chicken & & & & & \\
seeds (X3)
\end{tabular}

Dependent Variabel: Y

Source: Data processed with SPSS 20 
Based on the $t$ value and the significance value of the SPSS output above, it can be described as follows:

1. Based on the results of the study, it shows that the variable price of local chicken meat (X1) obtained the value of $t$ count $=13.691$ with the price of $t$ tablepada $\mathrm{df}=\mathrm{n}-\mathrm{k}(10-4)=$ 6 at the significant level of 0.05 , which is equal to 0.717 . From this explanation, it can be concluded that the value of tcount $>$ ttable $(13.691>0.717)$ and sig. Probability 0.000 $<0.05$. Thus H01 is accepted and Hal is accepted, explaining that there is a positive and significant effect of the price of Local chicken meat (X1) on the offer of Local chicken meat (Y).

2. Based on the results of the study showed that the variable price of local chicken feed (X2) obtained the value of $\mathrm{t}$ count $=-2.649$ with the price of $\mathrm{t}$ tablepada $\mathrm{df}=\mathrm{n}-\mathrm{k}(1-4)=6$ at the significant level of 0.05 was equal to 0.717 . From this explanation, it can be concluded that the value of $t$ count $<\mathrm{t}$ table $(-2.649<0.717)$ and sig. probability $0.038<0.05$. Thus Hol is rejected and Ha1 is accepted, explaining that there is a negative and significant effect of the price of local chicken feed (X2) on the offer of Local chicken meat (Y).

3 . Based on the results of the study showed that the variable price of village chicken seeds (X3) obtained the value of $\mathrm{t}$ count $=-6.029$ with the price of $\mathrm{t}$ tablepada $\mathrm{df}=\mathrm{n}-\mathrm{k}(10-4)$ $=6$ at the significant level of 0.05 was equal to 0.717 . From this explanation, it can be concluded that the value of $t$ count $<\mathrm{t}$ table $(-6.029<0.717)$ and sig. Probability 0.001 $<0.05$. Thus Hol is rejected and Ha1 is accepted, explaining that there is a negative and significant effect of the price of Local chicken seed (x3) on the offer of Local chicken meat $(\mathrm{Y})$

e. Simultaneous Hypothesis Testing (Test - F)

Table 7. The Result of Simultaneous Test - F of ANOVA ${ }^{\mathrm{a}}$

\begin{tabular}{|l|r|r|r|r|r|}
\hline Model & $\begin{array}{c}\text { Sum of } \\
\text { Squares }\end{array}$ & Df & Mean Square & F & Sig. \\
\hline Regression &, 254 & 3 &, 085 & 320,700 &, $000^{\mathrm{b}}$ \\
Residual &, 002 & 6 &, 000 & & \\
Total &, 256 & 9 & & & \\
\hline
\end{tabular}

a. Dependent Variabel: $\mathrm{Y}$

b. Predictors: (Constant), X3, X2, X1

Source: Data processed with SPSS 20

Simultaneous testing ( $\mathrm{F}$ test) was carried out by comparing Fcount and Ftable with $\mathrm{dk}$ comparison $=\mathrm{k}$ (number of variables studied) and $\mathrm{dk}$ denominator $=\mathrm{nk}-1$ at a significant level of $95 \%$ and alpha $5 \%$, i.e. $\mathrm{dk}$ numerator $=3$ and $\mathrm{dk}$ denominator $=4$, then the amount is 6,59. Based on the results of the analysis above, it is obtained that Fcount $=320.700$ with a significant amount of 0.000 , and the value of Fcount $>$ Ftable $(320.700>6.59)$ and sig. probability $0.000<0.05$, because Fcount $>$ Ftable, and the significance level is smaller than alpha $(0.000<0.05)$ means that the hypothesis is accepted, so there is a positive and significant influence between the price of local chicken meat (X1), the price of local chicken feed ( X2), the price of local chicken seeds (X3), on the offer of local chicken meat in Pakpak Bharat Regency. 


\section{f. Coefficient of Determination (R2)}

Table 8. Results of the calculation of the coefficient of determination Model Summary ${ }^{\mathrm{b}}$

\begin{tabular}{|l|r|r|r|r|}
\hline Model & R & R Square & Adjusted R Square & $\begin{array}{c}\text { Std. Error of the } \\
\text { Estimate }\end{array}$ \\
\hline 1 &, $997^{\mathrm{a}}$ &, 994 &, 991 &, 01625539 \\
\hline
\end{tabular}

a. Predictors: (Constant), X3, X2, X1

c. Dependent Variabel: Y

Source: Data processed with SPSS 20

Based on the output, the $\mathrm{R}$ square number is 0.994 or $99.4 \%$, thus showing that the price of local chicken meat (X1), the price of local chicken feed (X2), the price of local chicken seeds (X3) together have an influence on the dependent variable namely the offer of local chicken meat in Pakpak Bharat Regency (Y) of 99.4\%, and the remaining $0.6 \%$ of the offer of local chicken in Pakpak Bharat Regency is influenced by other variables that are not included in this research model, which can become further research.

\subsection{Projection Trend of Local Chickens Production Growth in Pakpak Bharat Regency} in 2020 - 2029

Forecasting analysis of local chicken production in Pakpak Bharat Regency in 20202029 was obtained by doing through Trend (long-term motion) using the Least Squares Method (least squares method) through the SPSS program using Simple Linear Regression, using data on chicken meat production in Pakpak Regency Bharat in 2010 - 2019, obtained the trend equation (attachment):

$$
\begin{gathered}
Q^{*}=a+b x^{*} \\
Q^{*}=14157+266,33 x^{*}
\end{gathered}
$$

From the equation obtained, it can be seen that the production of local chickens for 2020-2029 by replacing the $\mathrm{x}$ value in the equation with the $\mathrm{x}$ value that has been determined for that year. The equation obtained shows a positive trend, every year there is an increase in the production of local chickens by $296.33 \mathrm{Kg}$.

Table 9. Forecasting Results of Village Chicken Production in Pakpak Bharat Regency Year

\begin{tabular}{lc} 
2020-2029 \\
\hline 2020 & Free -arange Chicken Production $(\mathrm{Kg})$ \\
2021 & 17417 \\
2022 & 18009 \\
2023 & 18602 \\
2024 & 19195 \\
2025 & 19787 \\
2026 & 20380 \\
2027 & 20973 \\
2028 & 21565 \\
2029 & 22158 \\
\end{tabular}

Source: Researcher's Calculation Results (2020) 
Based on table 9 above, it can be seen that each year there is an increase of $296.33 \mathrm{Kg}$, where in 2020 the forecasting of Local chicken production is estimated at $17,417 \mathrm{Kg}$ and it is estimated that in 2029 it will be $22,751 \mathrm{Kg}$.

\section{Conclusion}

Based on the results of the analysis that has been carried out regarding the factors that affect the demand and supply of Local chicken meat in Pakpak Bharat Regency, the following conclusions are obtained:

1. Simultaneously and partially the price of local chicken meat, tilapia meat price, population and income per capita have a significant effect on the demand for local chicken meat in Pakpak Bharat Regency.

2. Simultaneously and partially the price of local chicken meat, feed price, and seed price have a significant effect on the supply of local chickens in Pakpak Bharat Regency.

3. The production of local chickens in Pakpak Bharat Regency has a positive trend, meaning that there is an increase from year to year $(2020-2029$

\section{References}

Arsyad, L. (2000). Ekonomi Manajerial. Yogyakarta: BPFE-Yogyakarta.

Badan Pusat Statistik. 2010 - 2019. Pakpak Bharat dalam angka. Kabupaten Pakpak Bharat: BPS.

Dewanti, R. and Ginda S. (2012). Analisis Pendapatan Usaha Peternakan Ayam Buras (Studi Kasus di Kecamatan Tegalombo, Kabupaten Pacitan). Buletin Peternakan, 36 (1): 48-56.

Direktorat Jenderal Peternakan dan Kesehatan Hewan. (2017). Buku Statistik Peternakan dan Kesehatan Hewan Tahun 2017. Jakarta: Direktorat Jenderal Peternakan dan Kesehatan Hewan.

Hadini, H.A., Sudi N., Endang S. (2011). Analisis Permintaan dan Prediksi Konsumsi Serta Produksi Daging Broiler di Kota Kendari Propinsi Sulawesi Tenggara. Buletin Peternakan, 35 (3): 202-207.

Hanani, N. and Kardono. (2004). Teori Ekonomi Makro: Pendekatan Grafis dan Matematis. Malang: Fakultas Ekonomi Universitas Brawijaya.

Hartono, G. (2012). Analisis Penawaran Ayam Pedaging (Broiler) di Tingkat Petani. Majalah Ilmiah Peternakan, 10 (3): 1-16.

Kurniati, S.A. (2014). Peran Sektor Peternakan Ayam Pedaging dalam Perekonomian Kabupaten Kuantan Singingi Propinsi Riau. Jurnal Peternakan Indonesia, 16 (3): 170178.

Mankiw, N.G. (2006). Pengantar Ekonomi. Erlangga. Jakarta.

Nuraini, M. (2014). Analisis Faktor-Faktor Penentu Persistensi Laba. Skripsi. Semarang: Universitas Diponegoro Semarang.

Rohim, A. (2017). Analisa Faktor yang Mempengaruhi Permintaan Daging Ayam Broiler di Pasar Tradisional Kecamatan Citeureup Kabupaten Bogor. Skripsi. Bogor: Fakultas Ekonomi dan Manajemen IPB.

Sayuti, R. (2002). Prospek Pengembangan Agribisnis Ayam Kampung sebagai Usaha Ekonomi di Pedesaan. FAE, 20 (1): 40-49.

Siahaan, Ronald. (2011). Analisis Faktor-Faktor Yang Mempengaruhi Permintaan dan Penawaran Daging Sapi di Sumatera Utara. Tesis. Medan. USU. 
Shinta, H. et al. (2020). Potential Stunting in Riverside Peoples (Study on Pahandut Urban Village, Palangka Raya City). Budapest International Research and Critics InstituteJournal (BIRCI-Journal). P. 1618-1625

Sukirno, S. (2008). Pengantar Teori Mikro Ekonomi. Jakarta: PT. Raja Grafindo Persada. Sutrisno. H. (2004). Analisis Regresi. Yogyakarta: Ando Offset.

Utomo, H.R., H. Setiyawan, S.I, Santoso. (2015). Analisis Profitabilitas Usaha Peternakan Ayam Broiler dengan Pola Kemitraan di Kecamatan Limbangan Kabupaten Kendal. Animal Agriculture Journal, 4 (1): 7-14. 